\title{
The influence of dietary sulphur loading on metabolism and health in young sheep fed low fibre and high starch diet
}

\author{
Barbara Krasicka*, Mikolaj A. Gralak, Bogumila Sieranska, \\ Gustaw Kulasek \\ Department of Animal Physiology, Faculty of Veterinary Medicine, \\ Warsaw Agricultural University, Nowoursynowska 166, 02-787 Warsaw, Poland
}

(Received 16 May 1998; accepted 20 September 1999)

\begin{abstract}
The purpose of the experiment was to evaluate the long-term effect of a low roughage diet (7-8 \% CF) with or without sulphur (S) supplementation (elemental and sodium sulphate 1:1) on basal dietary components, $\mathrm{Zn}, \mathrm{Cu}$ and $\mathrm{S}$ availability, rumen metabolism and health in growing sheep. The control diet contained $0.2 \%$ and the supplemented diet $0.8 \%$ of $\mathrm{S}$ on a DM basis. The experiment lasted 12 weeks. The intake of the diet with $0.8 \%$ of S resulted in an increase in rumen acetic acid concentration. Rumen lactic acid concentrations in S-supplemented versus control sheep were higher in the first and lower in the third month, and decreased at the end of the third month of the experiment in both groups. Blood plasma pyruvate was lower at the end of the experiment in S-supplemented sheep than in control sheep. In the 5 th week of the experiment, the high $\mathrm{S}$ diet depressed basal nutritional components as well as $\mathrm{Zn}$ and $\mathrm{Cu}$ availability. After 12 weeks of feeding of this diet, polioencephalomalacia had developed in all sheep. (C) Inra/Elsevier, Paris
\end{abstract}

sheep / sulphur loading / low roughage diet / digestibility / polioencephalomalacia

Résumé - Influence d'une surcharge alimentaire en soufre sur le métabolisme et la santé d'agneaux recevant un régime pauvre en fibres et riche en amidon. L'objectif de l'expérience était d'évaluer l'effet à long terme d'un régime comportant une quantité de fibres faible (7-8\% fibres brutes (FB)) avec ou sans supplément de soufre (soufre élémentaire et sulfate de soude 1:1) sur l'utilisation des constituants de base du régime, sur les disponibilités de $\mathrm{Zn}, \mathrm{Cu}$ et $\mathrm{S}$, sur le métabolisme du rumen et sur la santé des moutons en cours de croissance. Le régime des sujets témoins contenait $0,2 \% \mathrm{~S}$ et le régime supplémenté $0,8 \% \mathrm{~S}$ (par rapport à la matière sèche). Le régime supplémenté en $\mathrm{S}(0,8 \%)$ conduit à une augmentation de la concentration en acide acétique dans le rumen. La concentration en acide lactique dans le rumen des moutons ayant reçu le supplément en $\mathrm{S}$ comparée à celle des moutons témoins était plus importante pendant le premier mois et plus faible pendant le troisième mois. Cette concentration a diminué à la fin du troisième mois expérimental chez les mou-

\footnotetext{
* Correspondence and reprints

E-mail: gralak@alpha.sggw.waw.pl
} 
tons appartenant aux deux groupes. Le taux plasmatique du pyruvate était plus faible à la fin de l'expérience chez les moutons ayant reçu un supplément de $\mathrm{S}$ que chez les moutons témoins. Au cours de la $5^{\mathrm{e}}$ semaine de l'expérience, la teneur élevée en $\mathrm{S}$ du régime alimentaire a diminué les taux des constituants basaux du régime ainsi que les disponibilités de $\mathrm{Zn}$ et $\mathrm{Cu}$. Après 12 semaines d'alimentation avec ce régime, la polioencéphalomalacie s'est développée chez tous les moutons. (C) Inra/Elsevier, Paris

\section{mouton / apport de soufre / régime pauvre en fibres / digestibilité / polioencéphalomalacie}

\section{INTRODUCTION}

The effect of a dietary sulphur supplement on food intake, body gain, organ development and digestibility of dietary components was studied in sheep by Slyter et al. [36], Yada and Mandokhot [43], Fleck and Shurson [10], and many other authors. Sulphur is an essential element for the normal development of rumen bacteria, especially for the synthesis of the sulphur amino acids and may improve fibre and organic matter digestibility $[7,8,33,36]$. Sulphur-containing amino acids are essential for tissue protein synthesis and other sulphur-containing metabolites. According to NRC [26], sulphur content in the ruminant diet should be in the range $0.1-0.3 \%$ on a DM basis and this is why it is often added to ruminant diets, especially those containing non-protein nitrogen. The S overdose can, however, significantly disturb metabolism and animal health $[21,43]$. Occurrence of polioencephalomalacia (PEM) as a result of S overdose was reported by Raisbeck [34], Olkowski et al. [28], Hamlen et al. [15], Bulgin et al. [2], Alves de Oliveira et al. [1] and Low et al. [23]. The exact mechanism(s) of $\mathrm{S}$ loading in PEM development has been discussed. Dietary $S$ overdoses may disturb rumen metabolism, e.g. it may increase the thiamine-destroying activity [29] which in turn may lead to thiamine deficiency and/or increase the rate of sulphate reduction to sulphides [1, 27]. Both of these cases can trigger the development of PEM. Recent studies on sulphur-induced PEM have indi- cated that thiamine deficiency is not the primary cause of this disease but rather sulphides absorbed from the rumen of S-loaded animals $[12,27]$.

The purpose of the present experiment was to study the effect of a low roughage diet supplemented with $0.8 \%$ sulphur on a DM basis on nutrient digestibility as well as on rumen metabolism of nutrients and to check whether the sulphur-dependent polioencephalomalacia is associated with disturbances of the gastrointestinal processes.

\section{MATERIALS AND METHODS}

The experiment lasted 12 weeks and was performed on 15 Polish Merino sheep aged 3 months. At the beginning of the experiment the animals weighed $18-23 \mathrm{~kg}$. Animals were divided into three feeding groups according to weight. The sheep in the control group were offered meadow hay and an extruded concentrate in a ratio $1: 1$, whereas experimental groups 1 and 2 received a low fibre diet consisting of hay and extruded concentrate enriched with potato starch (1:3.7) (table I). The diet of experimental group 2 was additionally supplemented with enough sulphur to obtain $0.8 \% \mathrm{~S}$ on a DM basis in the final diet. Sulphur was added to the concentrate before extrusion, in the form of elemental $\mathrm{S}$ and $\mathrm{Na}_{2} \mathrm{SO}_{4}$ in a 1:1 $\mathrm{S}$ ratio basis. After careful mixing the components of the concentrate were extruded at $145^{\circ} \mathrm{C}$ (single screw extruder - Insta-Pro 600). The composition of the diets is presented in table I. An extruded concentrate was offered in two equal portions at 8 a.m. and 4 p.m.; hay was offered $2 \mathrm{~h}$ following the morning feeding of the concentrate; water 
Table I. Composition of diets of the sheep.

\begin{tabular}{lccc}
\hline Item & \multicolumn{3}{c}{ Group/treatment } \\
\cline { 2 - 4 } & Control group & 1 (Low fibre) & 2 (Low fibre $+\mathrm{S})$ \\
\hline Daily doses offered: & & & \\
$\quad$ Extruded concentrate $\left(\mathrm{g} \cdot \mathrm{d}^{-1}\right)$ & 450 & 550 & 550 \\
Meadow hay $\left(\mathrm{g} \cdot \mathrm{d}^{-1}\right)$ & 450 & 150 & 150 \\
Crude protein $\left(\mathrm{g} \cdot \mathrm{d}^{-1}\right)$ & $143(15.9 \%)$ & $139(19.9 \%)$ & $137(19.6 \%)$ \\
Crude fibre $\left(\mathrm{g} \cdot \mathrm{d}^{-1}\right)$ & $120(13.3 \%)$ & $53(7.6 \%)$ & $56(8.0 \%)$ \\
Sulphur $\left(\mathrm{g} \cdot \mathrm{d}^{-1}\right)$ & $1.37(0.15 \%)$ & $1.34(0.19 \%)$ & $5.02(0.72 \%)$ \\
N/S ratio & 16.7 & 16.6 & 4.4 \\
& & & \\
Percentage composition of extruded & & & \\
concentrate mixture: & 69.8 & 47.3 & 46.1 \\
Barley meal & 25.0 & 34.0 & 33.4 \\
Soybean meal & 2.7 & 2.7 & 2.7 \\
Fodder yeast & - & 13.5 & 13.5 \\
Potato starch & 2.5 & 2.5 & 2.5 \\
Polfamix $\mathrm{O}^{*}$ & - & - & 0.3 \\
Sulphur elemental & - & - & 1.5 \\
Sodium sulphate & & & \\
\hline
\end{tabular}

* Mineral mixture for sheep.

was available ad libitum. Samples of rumen contents were collected using the gastric tube at the beginning of the 5 th, 10 th and 12 th weeks, and samples of blood were obtained from the jugular vein at the beginning of the 5th and 10th weeks of feeding with the appropriate diets. The samples of rumen digesta and blood were taken before the morning feeding. Two balance trials, 5 days each, were performed during the 5 th week on all three groups and during the 10 th week only with the experimental groups 1 and 2 .

Samples of feeds, faeces and urine collected during balance trials were analysed according to the Weende method. Crude fibre and crude protein were estimated using Fibertec and Kjeltec (all Tecator AB, Hoganas, Sweden). Volatile fatty acids (VFA) [44] and lactate (Sigma A lactate test 826) as well as $\mathrm{pH}$ were determined in the liquid phase of rumen digesta. Pyruvate concentration in the plasma was estimated using the Sigma pyruvate test 726 . For mineral determination, samples of feeds and faeces were digested with $\mathrm{HNO}_{3}$ (Merck 1.00441) in hermetic Teflon vessels in a microwave oven and $\mathrm{Cu}$ and $\mathrm{Zn}$ were estimated by flame atomic absorption spectrometry (Perkin-Elmer 1100B). Total sulphur was determined using a chemical method [3]. Microbial protein synthesis was calculated on the basis of daily allantoin excretion in urine [40].

For statistical evaluation two way analysis of variance (group*period) was used. When the interaction between factors was significant, one way analysis of variance was applied [41]. The significance of differences between groups was evaluated by the Tukey test (Statgraphics Plus 6.0). Differences at $P \leq 0.05$ were considered statistically significant.

\section{RESULTS}

The mean body gain ranged from 133 to

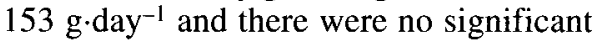
differences between groups. The overall means of volatile fatty acid content in the rumen fluid are presented in table II. Supplementation of sulphur of the low fibre diet (group 1 versus group 2) increased the concentration of acetic acid at the expense of 


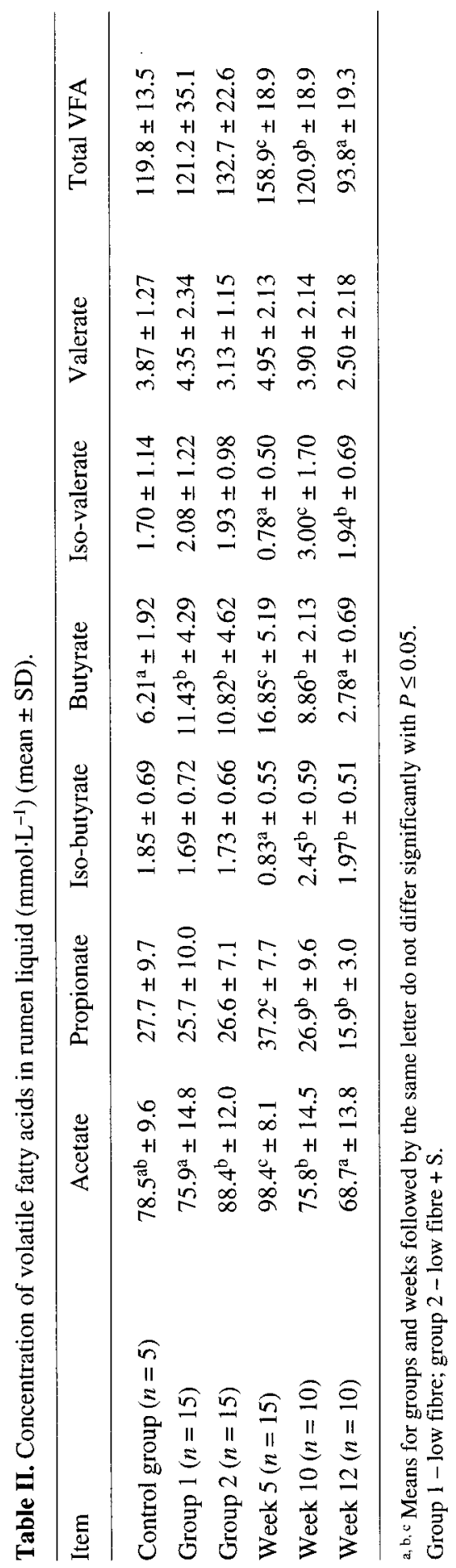




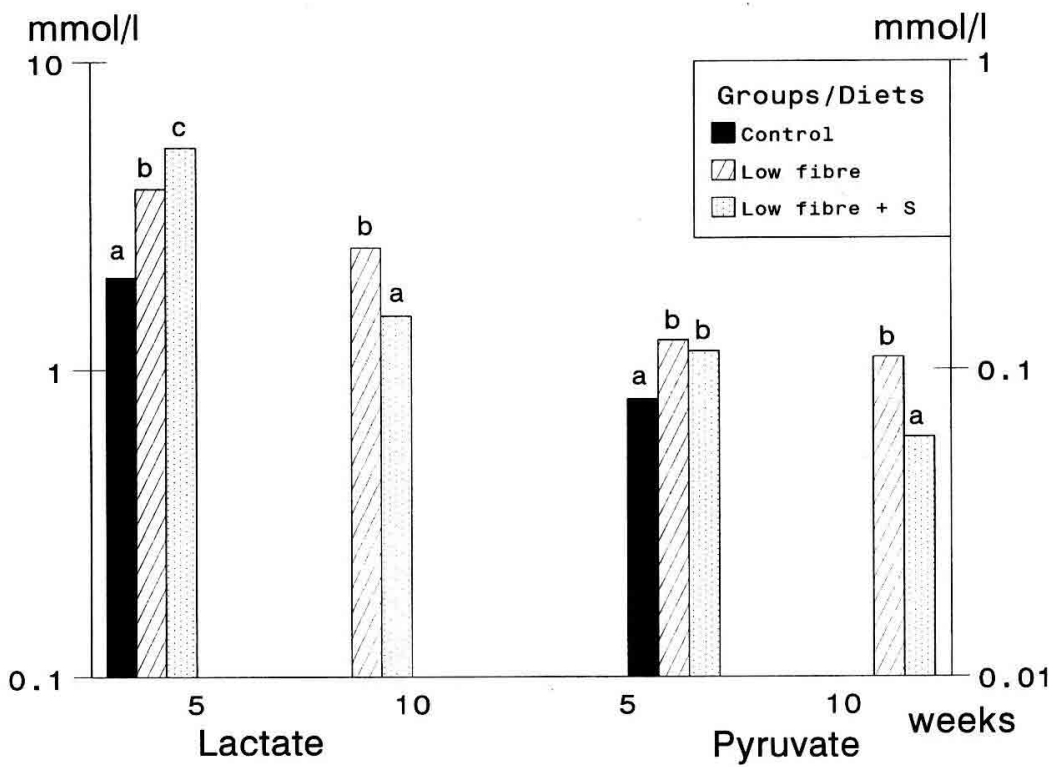

Figure 1. Concentration of lactate in the rumen fluid and pyruvate in the blood of young sheep in the 5 th and 10th weeks of the experiment, ${ }^{\text {a, b, }}$ Bars tagged with the same letter do not differ significantly with $P \leq 0.05$.

other VFAs in the rumen fluid (table II). In both groups the total fatty acids, acetic, propionic and butyric acids decreased with the length of the experiments (5th versus 10th versus 12 th weeks). The concentration of lactic acid in the rumen fluid was in general moderate in both experimental groups, which did not indicate any acidotic symptoms. In the 5th week of the experiment, however, lactic acid was higher in sulphursupplemented sheep (group 2) than in sheep from group 1 . This result was reversed in the 10 th week (figure I). Rumen microbial protein synthesis, estimated on the basis of urine allantoine excretion, was similar in both groups (table III). There was no difference between low fibre groups in pyruvate in blood plasma in the 5 th week of the experiment but a longer S loading (10th week) caused a significant decrease in pyruvate in blood plasma of the sheep (figure 1).

We observed differences in nutrient balance only in the 5 th week but not in the 10th week (table III). Digestibility of dry matter and organic matter was significantly higher in sheep fed a low fibre diet (group 1). Nitrogen digestibility was lower $(P \leq 0.05)$ in the control group. Applying two-way analysis of variance (period ${ }^{*}$ group), we found significant differences between periods ( 5 th versus 10 th week). We observed a significant decrease in DM digestibility $(79.9 \pm 2.7$ versus $73.4 \pm 2.7, n=9$ ), OM digestibility $(81.4 \pm 2.1$ versus $75.8 \pm 2.1, n=9)$ as well as CF digestibility ( $48.4 \pm 7.7$ versus 29.9 $\pm 7.7, n=9$ ). Taking into account the overall averages from both periods (5th and 10th weeks), we also estimated a significant influence of S supplementation on CF digestibility $(44.3 \pm 7.7$ - group 1 versus $34.0 \pm 7.7-$ group 2).

Sulphur supplementation of a low fibre diet increased sulphur retention but lowered the retention of $\mathrm{Zn}$ in the first balance trial (table IV). Copper was excreted only in the faeces, $\mathrm{Zn}$ mainly in the faeces (>90\%) and sulphur mainly in the urine and in the first balance trial, this amounted to 76 and $90 \%$ 


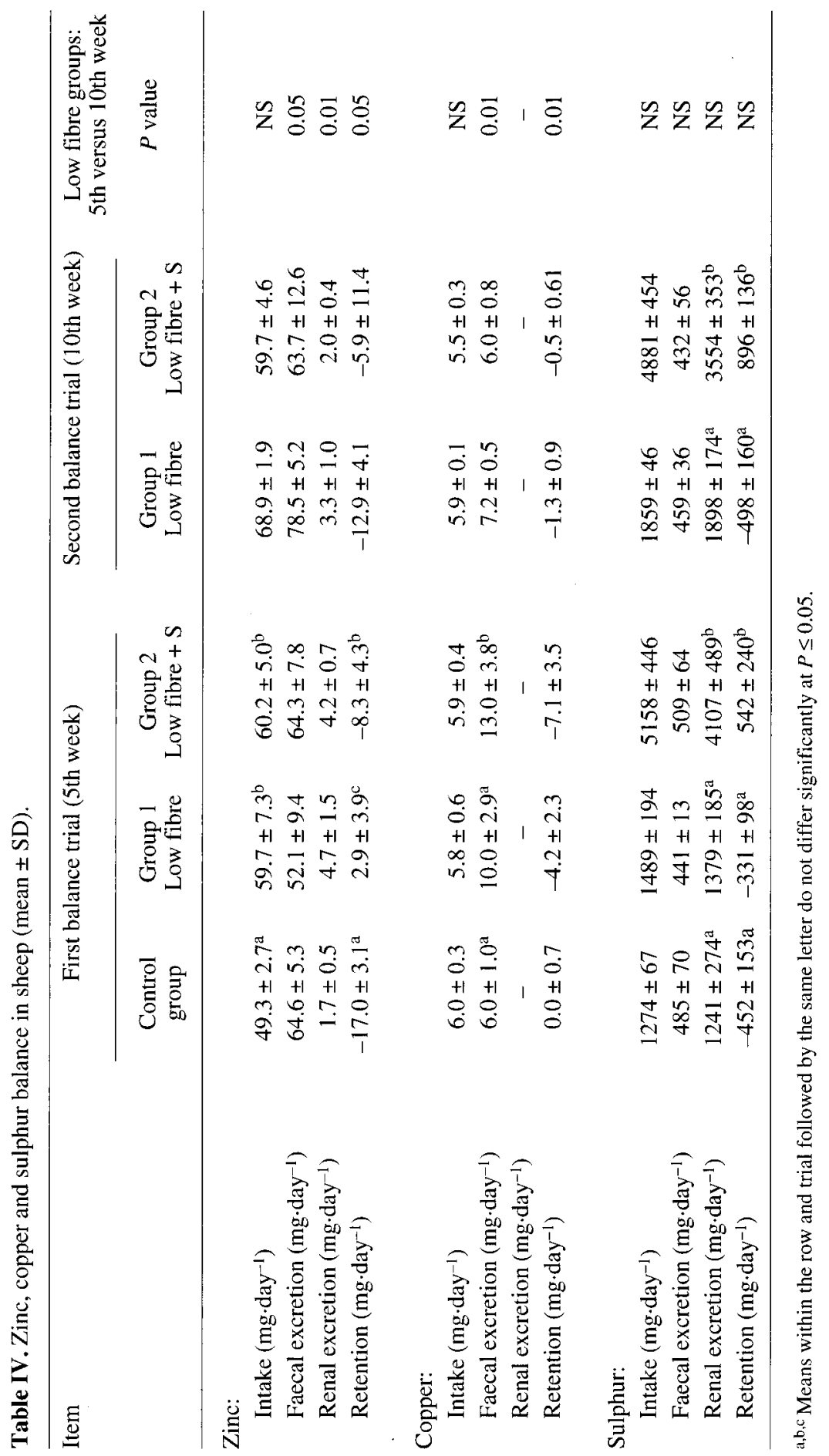


of total $\mathrm{S}$ excreted for the groups 1 and 2, respectively, and in the second balance trial 80 and $89 \%$ for the groups 1 and 2, respectively.

The considerable effect of S supplementation was revealed in the 12 th week of experimentation when all animals of group 2 became ill. Clinical and postmortem histopathological symptoms revealed polioencephalomalacia (PEM). Clinical symptoms were very acute. Characteristic stance was observed: animals extended heads and necks turning them over the right shoulder. They lost appetite, respired with difficulty and had an aversion to light. Tachycardia (160-180) was also observed. After 3-4 h, the symptoms became more acute. They had involuntary contractions of limb muscles that in turn disturbed motor function. Often lambs were prostrated and convulsions were observed. Fits of convulsions lasting 3-5 min were repeated after 10-15-min intervals. No animal recovered after thiamine administration. All affected sheep were slaughtered and the tissues were collected for histopathological studies. Brain analysis showed extensive focal lesions in the grey matter, extensive haemorrhage and extravasation, haemorrhagic meningoencephalitis. Necropsy also revealed extensive pulmonary oedema and multiplied small focuses of emphysema in the intestines. No pathological changes in the liver were noted. The results of necropsy were similar to those reported by Olkowski et al. [28] and Bulgin et al. [2].

\section{DISCUSSION}

Sheep from all groups had very high concentrations of rumen VFA during the first month of the experiment. This could be associated with very high temperatures during that period, hence animals preferred to eat late in the evenings and early in the mornings. They also did not usually intake the whole diets. In the consecutive weeks of the experiment (10th and 12th) VFA con- centrations in sheep of both experimental groups decreased continuously (table II). This decrease was accompanied by a drop in the rumen lactic acid concentration in the 10th week of the experiment compared to the 5 th week (figure 1). This is in agreement with the results presented by Qi and Owens [32]. All animals were fed extruded concentrate, and it is well known that extruded/expanded feeds are quickly fermented in the rumen mainly because of starch gelatinisation [6]. A decrease in VFA production during the long administration of the low fibre and high concentrate diet was observed not only in the present study but also in the studies of Hishikavo et al. [16] and Kostos and Bray [19]. It is noted that sulphur supplementation of a low fibre diet increases the concentration of acetic acid (table $I$ ), therefore having a significant effect on fibre digestibility (table III). Alves de Oliviera et al. [1] fed sheep a semipurified diet with $33 \%$ of cellulose and $0.6 \% \mathrm{~S}(0.4 \% \mathrm{~S}$ as ammonium sulfate + $0.2 \%$ as sodium sulphate) versus $0.2 \% \mathrm{~S}$ on a DM basis and observed no statistical difference in VFA levels. In sheep fed high $S$ diets, however, there was a tendency towards a lower level. In our experiment, when sheep were fed a low fibre diet (about $8 \% \mathrm{CF}$ ), the $\mathrm{S}$ supplement (to $0.8 \% \mathrm{~S}$ in $\mathrm{DM}$ ) promoted the bacteria of acetic fermentation but did not significantly change the total VFA concentration. The low fibre diet evoked an increase in butyrate production during the first month of the experiment which was in accordance with the results obtained by Orskov and Ryle [30]. It may be interesting to note that in group 1 during the first balance trial, rumen microbial protein synthesis was the lowest (table III). This suggests that during this period, rumen bacteria were not yet fully adapted to the diet rich in readily digestible carbohydrates containing $0.23 \%$ (DM) of sulphur. At the same time, the $\mathrm{S}$ supplement in group $2(0.78 \% \mathrm{~S}$ in DM) improved conditions for microbial protein synthesis. These results may suggest that low fibre diets need higher concentrations of 
sulphur than the $0.2-0.3 \%$ (DM basis) recommended. Generally our results are in agreement with those of Alves de Oliveira et al. [1]. Moreover, they suggest that the ecosystem of the rumen is very resistant to high sulphur levels in diets.

It seems that the high $\mathrm{S}$ intake might depress OM digestibility after 1 month of feeding with a low fibre diet. The narrow N/S ratio in group 2 (table $I$ ) affected the apparent crude fibre digestibility (table III). Morrison et al. [25] and Qi et al. [33], however, observed that a $\mathrm{N} / \mathrm{S}$ ratio ranging from 16:1 to $4: 1$ did not change the in vivo organic matter digestibility, but increased the rate of rumen DM degradability. This was not the case in this experiment.

The apparent digestibility of basal components (DM, OM and CP) was higher in the first balance trial and decreased with time. This phenomenon was associated with the high starch content in the diet that was also observed by Taniguchi et al. [39]. In the first balance trial, dietary sulphur loading $(0.8 \%$ in DM) in group 2 depressed digestibility of the above-mentioned components (table III). After 9 weeks of the experiment we did not observe any inhibitory effect of dietary sulphur loading on the apparent digestibility of these components (table III) which may indicate an adaptation of the digestible processes to the higher dietary sulphur content.

Long-term feeding of the high starch and low fibre diet decreased cellulolytic activity in the rumen (table II). Hishikavo et al. [16] and Kostos and Bray [19] obtained similar results. This may be explained by the availability of starch, which was preferentially digested by cellulolytic bacteria instead of cell wall carbohydrates [42]. This process is, usually, accompanied by a decrease in rumen fluid $\mathrm{pH}$. In this study, no significant differences in rumen $\mathrm{pH}$ between the groups were observed. In the first balance trial, the $\mathrm{pH}$ ranged from $6.51 \pm 0.29$ (group 2) to $6.91 \pm 0.39$ (control group). However, prolonged consumption of the high starch and low fibre diet reduced the $\mathrm{pH}$ values to 5.98 \pm 0.44 (group 1) and $5.82 \pm 0.52$ (group 2).

The sulphur retention in group 2 was the highest (table IV), probably because the inorganic S supplement was well absorbed. Long-term feeding with the high starch, low fibre diets resulted in the negative apparent absorption and retention of both $\mathrm{Zn}$ and $\mathrm{Cu}$, even though the intake of $\mathrm{Zn}$ and $\mathrm{Cu}$ was at the upper limit recommended by NRC [26]. This is why the results concerning microelements are very difficult to interpret. The $\mathrm{Cu}$ availability could be affected by a wide dietary $\mathrm{Zn} / \mathrm{Cu}$ ratio (10:1) which is higher than the 4:1 ratio considered to be optimal [31]. Disorders of $\mathrm{Zn}$ and $\mathrm{Cu}$ absorption in sulphur loaded sheep have also been reported by Lamand et al. [21]. Gooneratne et al. [11] showed that excessive dietary levels of molybdenum and sulphur increase biliary $\mathrm{Cu}$ and $\mathrm{Zn}$ excretion which in turn can induce negative retention of these elements. Moreover, continuous feeding of a readily fermented diet can decrease $\mathrm{Cu}$ availability in sheep [38]. The negative sulphur retention in groups fed diets without $S$ supplementation (1) suggests that there was an insufficient amount of this element in the control diet.

From the results discussed it seems that sulphur supplementation (up to $0.8 \% \mathrm{DM}$ ) of a low fibre diet did not affect rumen metabolism and digestibility of the basal compounds and minerals. After 12-13 weeks, however, animals fed this diet became lethally ill. The symptoms were similar to those observed by Krasicka et al. [20] in young sheep loaded with amprolium. Amprolium is an antagonist of thiamine, so it was suggested that it could be used as a model factor causing PEM in ruminants [22, 37]. Krasicka et al. [20] reported that three Amprolium ill animals recovered after injection of vitamin $B_{1}$. In other studies polioencephalomalacia was also suspected and the clinical condition of lambs returned to normal after treatment with thiamine [23, 35]. Olkowski et al. [28] stated that thiamine 
plays a critical role in the prevention of clinical signs and lesions of sulphur-induced polioencephalomalacia in sheep. Nevertheless, they claimed that dietary sulphur supplements had no major effect on blood thiamine status. In the present study we observed the rapid onset of acute PEM symptoms in group 2 . This may have been due to relatively low $\mathrm{pH}$ in the rumen fluid, which may have contributed to the toxicity of sulphur [2] and to hot weather [24]. The animals did not respond to thiamine treatment. Also, other authors have stated that thiamine treatment is not of value in most animals with PEM related to high sulphur intake [2, 18, 34]. Low et al. [23] also evoked PEM in sheep by feeding a high sulphur diet with a low fibre content. It seems that low crude fibre content in diets can increase the severity of PEM symptoms. Jean-Blain et al. [17] observed, in vitro, that an excess of sulphur slightly decreases the net microbial production of thiamine but this was not confirmed in later in vivo studies $[1,24]$. They concluded that a large amount of the sulphur in the diet had no effect on the thiamine level in the rumen fluid, hence it could not induce thiamine deficiency. On the contrary, the total blood thiamine level is not a good diagnostic criterion in polioencephalomalacia; the better criterion could be brain thiamine concentration [9]. In other studies, it was stated that polioencephalomalacia is associated with the excessive production of sulphide anion in rumen fluid [13, 24]. Gould et al. [14] found that the $\mathrm{H}_{2} \mathrm{~S}$ in the gas compartment undergoes much more dramatic changes than sulphide in the rumen fluid compartment. The role of bacteria in this process is not clear. Cummings et al. [4, 5] did not observe changes in the total and sulphate-reducing bacterial numbers attributable to dietary sulphate content. Only colonytype profiles indicate a decreased diversity of bacteria cultured from rumen fluid samples of cattle fed high carbohydrate, and low fibre diets. They suggested that rumen micro-organisms adapt to higher dietary sul- phate content before they are capable of generating potentially toxic concentrations of sulphide.

\section{CONCLUSIONS}

Twelve weeks of feeding with diets rich in sulphur $(0.8 \%$ on DM) and low in fibre evoked polioencephalomalacia in young sheep. The diets used did not significantly depress digestibility of basal components nor rumen microbial protein synthesis. Further investigations on this problem are needed to better understand the role of dietary factors in illness production.

\section{REFERENCES}

[1] Alves de Oliveira L., Jean-Blain C., Dal Corso V., Benard V., Durix A., KomisarczukBony S., Effect of a high sulpur diet on rumen microbial activity and rumen thiamine status in sheep receiving a semi-synthetic, thiamine-free diet, Reprod. Nutr. Dev. 36 (1996) 31-423.

[2] Bulgin M.S., Lincoln S.D., Mather G., Elemental sulpur toxicosis in a flock of sheep, J. Am. Vet. Med. Assoc. 208 (1996) 1063-1065.

[3] Butters E., Chenery E.M., Sulphur determination in organic matter, The Analyst 89 (1959) $633-635$.

[4] Cummings B.A., Caldwell D.R., Gould D.H., Hamar D.W., Identity of interactions of rumen microbes associated with dietary sulfate-induced polioencephalomalacia in cattle, Am. J. Vet. Res. 56 (1995) 1384-1389.

[5] Cummings B.A., Gould D.H., Caldwell D.R., Hamar D.W., Ruminal microbial alterations associated with sulfide generation in steers with dietary sulfate-induced polioencephalomalacia, Am. J. Vet. Res. 56 (1995) 1390-1395.

[6] Davidson V.J., The rheology of starch-based materials in extrusion process, in: Kokini J.L, Ho C.T, Karwe M.V. (Eds.), Food Extrusion Science and Technology, M. Dekker, Inc., New York, 1992, pp. 263-275.

[7] Durand M., Komisarczuk S., Effect of some major minerals on rumen microbial metabolism in a semi-continuous fermentor Rusitec, Med. Fac. Landbouw. Riksuniv. Gent. 52 (1987) 1655-1663.

[8] Durand M., Komisarczuk S., Influence of major minerals of rumen microbiota, J. Nutr. 118 (1988) $249-260$. 
[9] Edwin E.E., Jackman R., Ruminal thiaminase and tissue thiamine in cerebrocortical necrosis, Vet. Rec. 92 (1973) 640-641.

[10] Fleck M., Shurson G.C., Effects of sulfate in drinking water for livestock, J. Am. Vet. Med. Assoc. 201 (1992) 487-492.

[11] Gooneratne S.R., Symonds H.W., Bailey J.V., Christensen D.A., Effects of dietary copper, molybdenum and sulphur on biliary copper and zinc excretion in Simmental and Angus cattle, Can. J. Anim. Sci. 74 (1994) 315-325.

[12] Gould D.H., Polioencephalomalacia, J. Anim. Sci. 76 (1998) 309-314.

[13] Gould D.H., McAllister M.M., Savage J.C., Hamar D.W., High sulfide concentrations in rumen fluid associated with nutritionally induced polioencephalomalacia in calves, Am. J. Vet. Res. 52 (1991) 1164-1169.

[14] Gould D.H., Cummings B.A., Hamar D.W., In vivo indicators of pathologic ruminal sulfide production in steers with diet-induced polioencephalomalacia, J. Vet. Diagn. Invest. 9 (1997) $72-76$.

[15] Hamlen H., Clarc E., Janzen E., Polioencephalomalacia in cattle consuming water with elevated sodium sulphate levels: A herd investigation, Can. Vet. J. 34 (1993) 153-158.

[16] Hishikavo M., Oura R., Sekine J., Changes in ruminant volatile fatty acids and microflora of fattening steers fed concentrate from $50-90 \%$ in ration, J. Fac. Agric. Tottori Univ. 24 (1988) 55-60.

[17] Jean-Blain C., Alves de Oliveira L., Komisarczuk-Bony S., Durix A., Study in Rusitec of the effect of sulphur level and addition of thiamine on the microbial net production of thiamine in the rumen, in: Abstracts of the IXth International Conference on production disease in farm animals, Free University of Berlin, Germany, 1995, p. 111.

[18] Jeffrey M., Duff J.P., Higgins R.J., Simpson V.R., Jackman R., Jones T.O., Mechie S.C., Livesey C.T., Polioencephalomalacia associated with the ingestion of ammonium sulphate by sheep and cattle, Vet. Rec. 134 (1994) 343-348.

[19] Kostos K., Bray A., Effects of variation in so]uble carbohydrate intake on sulphur dynamics in the sheep rumen, J. Sci. Food Agric. 8 (1992) 489-498.

[20] Krasicka B., Gralak M., Podgurniak P., Polioencephalomalacia in sulphur loaded young sheep, in: Zwiazki mineralne w zywieniu zwierzat, Konferencja Naukowa 8-9 IX 1994, AR w Poznaniu, 1994, pp. 221-224.

[21] Lamand M., Lab C., Migon M., Tressol J.C., The influence of sulphur supplementation (methionine and sulphate) on the zinc availability of a poor diet in sheep, Ann. Res. Vet. 21 (1990) 229-230.
[22] Lonkar P.S., Prasad M.C., Induction of cerebrocortical necrosis in goats, Indian J. Anim. Sci. 62 (1992) 551-552.

[23] Low J.C., Scott P.R., Howie F., Lewis M., FitzSimons J., Spence J.A., Sulphur-induced polioencephalomalacia in lambs, Vet. Rec. 138 (1996) 327-329.

[24] McAllister M.M., Gould D.H., Raisbeck M.F., Cummings B.A., Loneragan G.H., Evaluation of ruminal sulfide concentrations and seasonal outbreaks of polioencephalomalacia in beef cattle in a feedlot, J. Am. Vet. Med. Assoc. 211 (1997) 1275-1279.

[25] Morrison M., Boniface A.N., Murray R.M., Alternation of supplement nitrogen: sulphur ratio by increasing sulphate supplementation affects the rate rather than the extend of fibre degradation in cattle fed matured tropical grass hay, J. Sci. Food Agric. 65 (1994) 440-455.

[26] NRC, Nutrient Requirement of Domestic Animals, Nutrient Requirement of Sheep, 5th ed., National Academy of Science. NRC, Washington D.C., 1985.

[27] Olkowski A.A., Neurotoxicity and secondary metabolic problems associated with low to moderate levels of exposure to excess dietary sulphur in ruminants: a review, Vet. Human Toxicol. 39 (6) (1997) 355-360.

[28] Olkowski A.A., Gooneratne S.R., Rousseaux C.G., Christensen D.A., Role of thiamine status in sulphur induced polioencephalomalacia in sheep, Res. Vet. Sci. 52 (1992) 78-85.

[29] Olkowski A.A., Laarved B., Patience J.F., Francis S.I., Christensen D.A., The effect of sulphate on thiamine-destroying activity in rumen content cultures in vitro, Int. J. Vit. Nutr. Res. 63 (1993) $38-44$.

[30] Orskov E.R., Ryle M., Energy Nutrition in Ruminants, Elsevier Applied Science, London, 1990.

[31] Puls R., Mineral Levels in Animal Health. Diagnostic Data, 2nd ed., Sherpa International, Clearbrook, Canada, 1994.

[32] Qi K., Owens F.N., Sulphate supplementation of growing goats; effects on performance, acidbase balance, and nutrient digestibilities, J. Anim. Sci. 71 (1993) 1579-1587.

[33] Qi K., Owens F.N., Lu C.D., Effects of sulphur deficiency on performance of fibre-producing sheep and goats: A review, Small Ruminant Res. 14 (1994) 115-126

[34] Raisbeck M.F., Is polioencephalomalacia associated with high sulphate diets?, J. Am. Vet. Med. Assoc. 180 (1982) 1303-1305.

[35] Sargison N.D., Scott P.R., Penny C.D., Pirie R.S., Polioencephalomalacia associated with chronic copper poisoning in a Suffolk ram lamb, Vet. Rec. 135 (1994) 556-557.

[36] Slyter L.L., Chalupa W., Oltjen R.R., Response to elemental sulpur by calves and sheep fed purified diets, J. Anim. Sci. 66 (1988) 1016-1027. 
[37] Spicer E.M., Horton B.J., Biochemistry of natural and amprolium-induced polioencephalomalacia in sheep, Aust. Vet. J. 57 (1981) 230-235.

[38] Suttle N.F., The interactions between cooper, molybdenum and sulphur in ruminant nutrition, Annu. Rev. Nutr. 11 (1991) 121-140.

[39] Taniguchi H., Sugihara M., Yamatuni Y., Otani I., Effects of starch supplementation on the fibre digestibility and the chewing time of hay consumed by sheep, Jpn. J. Zoot. Sci. 57 (1986) 12-13.

[40] Tiemeyer W., Giesecke D., Quantitative determination of allantoine chromatography, Anal. Biochem. 123 (1982) 11.
[41] Volk W., Statystyka stosowana dla inzynierow, Wydawnictwa Naukowo-Techniczne, Warszawa, 1965.

[42] Wedekind K.J., Muntifering R.B., Barker K.B. Effects of diet concentrate level and sodium bicarbonate on site and extent of forage fibre digestion in the gastrointestinal tract of wethers, J. Anim. Sci. 62 (1986) 1388-1395.

[43] Yada K.K., Mandokhot V.M., Effect of sulphur supplementation on the performance of stallfed Nali lambs, growth responds, nutrients, and mineral utilization, Indian J. Anim. Sci. 58 (1988) 843-848.

[44] Ziolecki A., Kwiatkowska E., Gas chromatography of $C_{1}$ to $C_{5}$ fatty acids in rumen fluid and fermentation media, J. Chromatogr. 80 (1973) 250-254. 